\title{
FORESTRY EDUCATION
}

\section{UNIVERSITY of GUELPH}

THE UNIVERSITY OF GUELPH, Guelph, Ontario, N1G 2W1 offers variety of undergraduate programs in natural resources management in the agricultural and forest sectors. Programs are designed to be interdisciplinary in order to explore the complexities involved in natural resources management and planning and yet are able to draw upon a wide range of expertise in the biological (especially plant) and physical sciences. A minor in Forest Science is offered through the Department of Environmental Biology and is available within many majors. The University also offers graduate degrees at the M.Sc. and Ph.D. levels and graduate work in many aspects of forest science is possible. Graduate work is also available in the field of agroforestry (the incorporation of trees into farming systems) in either temperate or tropical situations. Direct enquiries to the registrar at the address above or contact the Chair of the Department of Environmental Biology at (519) $824-4747$ ext. 3921

MALASPINA UNIVERSITY-COLLEGE, FOREST RESOURCES TECHNOLOGY PROGRAM. As a general objective, the program seeks to provide the technical training required for starting a career in most fields of forestry. The program emphasises the recognition and appreciation of all major forest values. The latest technology is taught and utilized, including handheld computers, GIS, GPS and multi-media references. The program is accredited by the Applied Science Technicians and Technologists (B.C.). In addition, several courses are recognized at the university level and by the Association of British Columbia Professional Foresters. Extensive use is made of the 1300 hectare woodlot, located within 10 minutes of the campus.

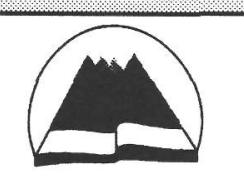

\section{Silviculture Institute of British Columbia \#270 - 2357 Main Mall, Vancouver, British Columbia V6T 124}

The Silviculture Institute of British Columbia (SIBC) is a non-profit society dedicated to improving silviculture on the forested lands of British Columbia through advanced education. SIBC offers three programs: UBC Diploma in Forestry (Advanced Silviculture), Technical Module Program, Silviculture 1\&2 Correspondence Courses. The UBC Diploma in Forestry (Advanced Silviculture) Program is offered to Registered Professional Foresters specializing in silvicultural practice with at least five years of forest management work experience. The objectives of the program are: to increase the participant's depth of understanding of the entire silviculture process; to assist participants in developing critical thinking and problem-solving skills to ensure defensible decision-making; to encourage participants to question the "status quo" and promote changes in forest management policies and procedures; and to promote the use of interdisciplinary teams to solve difficult natural resource management problems. The program is offered via six, two-week modules taken over a three year period in either a coastal or interior location in the province. The Technical Module Program is offered to forest technologists and technicians working in silviculture. Six one-week modules are taken over a three year period. The Silviculture 1\&2 Correspondence Courses are offered as part of the pre-registration requirements of the Association of B.C. Professional Foresters. For further information, contact Candace Parsons (Laird), Executive Director, (604) 224-7800, FAX: (604) 822-3106, or email claird@unixg.ubc.ca.

\section{Westviking College. \\ Fisher Building \\ P.O. Box 822 \\ Corner Brook, NF \\ Corner Brook Campus}

Westviking College of Applied Arts and Technology offers a group of programs in the Natural Resources Technology Field. The two year Forestry Resources Technology Diploma Program shares a common first semester with Programs in Environmental Science and Adventure Tourism. The Forestry Program includes a balance of lecture, lab and fieldwork experiences in forest utilization, protection, improvement and management. Students are exposed throughout to the use of computer technology in general and to Engineering Graphics and GIS software in particular. A wide range of specific technical subjects are included and delivered within the trend towards integrated management of our natural resources. For further information please direct enquiries to the above address or call (709) 637-8516.

THE UNIVERSTTY OF BRITISH COLUMBIA, Vancouver, British Columbia. The Faculty offers degree programs in Forest Resources Management (BSF), Forest Harvesting (BSF), Forest Science (BSc(Forestry)), Wood products processing (BSc(Forestry)), and Natural Resources Conservation (BSc(Natural Resources Conservation)). The BSF degree qualifies the graduate for registration in the Association of B.C. Professional Foresters. In addition to a basic common core, students must choose electives in interest areas or areas of concentration within each of the five major curriculums. The Faculty also offers programs leading to MSc, MASc, MF, and PhD degrees in most fields of Forest and Wood Sciences. A rich variety of forest types are found in the province of British Columbia, whose primary industries focus on the forests. The UBC campus is centred in a large greenbelt. The Faculty has two research and demonstration forests: the coastal Malcolm Knapp Research Forest in Maple Ridge (an hour's drive from the campus) and the Alex Fraser Research Forest, located in the interior forest, near Williams Lake. Direct enquiries to the Faculty of Forestry, 270-2357 Main Mall, Vancouver, BC, V6T 1Z4. Telephone: (604) 822-2727. Fax (604) 822-8645.

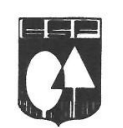

L'UNIVERSITÉ DE MONCTON. L'École de sciences forestières de l'Université de Moncton offre un programme d'études d'une durée de cinq ans menant au baccalauréat en sciences forestières (B. Sc. F.). Ce programme offre une formation à ceux et celles qui désirent faire carrière dans les domaines reliés à l'aménagement des ressources naturelles. II fournit à l'étudient(e) une formation globale dans la gestion de l'environnement forestier et vise à développer ses compétences et habilités en aménagement intégré et le développement durable des ressources forestières. Étant la seule institution francophone hors-Québec parmi les écoles de sciences forestières canadiennes, les diplômés peuvent devenir membre de corporations professionnelles et se prévaloir du titre 'Ingénieur forestier' au Québec et 'Forestier agréé' dans les autres provinces canadiennes. L'École de sciences forestières est située sur le campus d'Edmundston de l'Université de Moncton, région située dans un environnement forestier et bénéficiant des avantages de la présence de plusieurs utilisateurs de la forêt. Son enseignement personnalisé favorise une compréhension plus élaborée des matières de cours et permet d'offrir plusieurs sessions de laboratoires sur le terrain, ainsi que des stages pratiques en forêt et en milieu industriel. À environ quarante kilomètres du campus, l'École de sciences forestières gère une Forêt expérimentale de 830 hectares. Ce territoire est réservé pour les laboratoires des étudiant(e)s, la recherche, la récréation et la vulgarisation forestière. Les étudiant(e)s sont admis(e)s après avoir complété leurs études secondaires. Ceux et celles possédant une formation collégiale (cégep) peuvent obtenir des équivalences de cours. Pour plus de renseignements: Agent d'information, École de sciences forestières, 165, boulevard Hébert, Edmundston, N.-B. E3V 2S8. Téléphone: 1-800-561-9064 (sans frais) ou (506) 737-5241. Télécopieur: (506) 737-5373 Courrier électronique: Dlaplant@cusim.ca. Site Intemet. http://www.cusim.ca/ 


\section{FORESTRY EDUCATION}

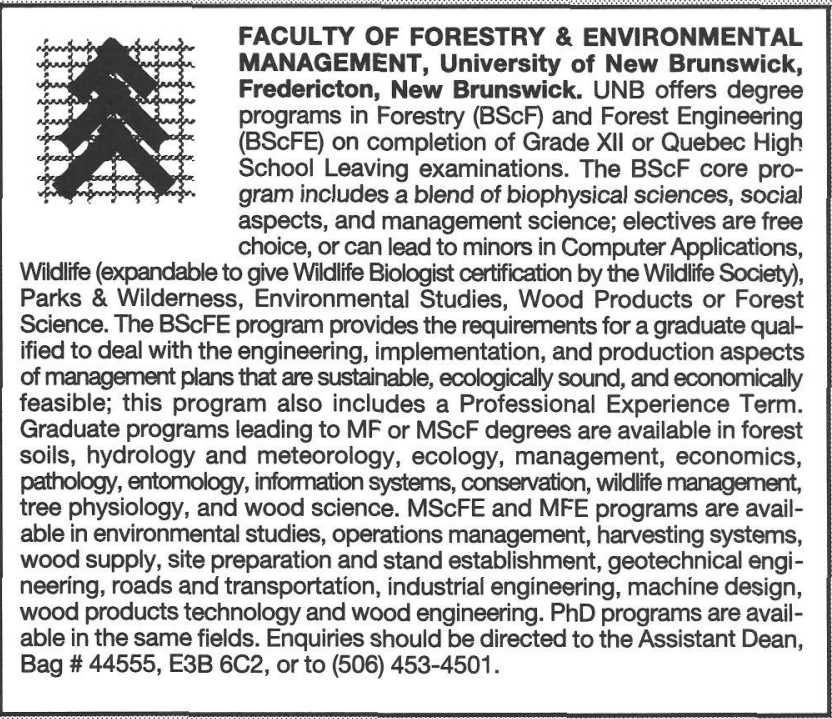

THE UNIVERSITY OF TORONTO, Toronto, Ontario. The Faculty
of Forestry at the University of Toronto offers graduate stud-
ies in research-oriented M.Sc.F. and Ph.D. programs and par-
ticipates in collaborative research programs in Environmental
Studies, at the master's level, and in Environmental Toxicology
at the master's and doctoral levels. Faculty research is direct-
ed to the areas of forest health and forest resource manage-
ment systems, including biological pest control, fire manage-

ENVIRONMENTAL TRAINING CENTRE, Hinton, Alberta. The Environmental Training Centre $(\mathrm{ETC})$ is an in-service training centre operated by Alberta Environmental Protection. The Centre offers a number of natural resource management courses including a unique and highly advanced fire control program which uses laserdisc technology for fire simulations. Members of the forest industry and other cooperating agencies are welcome to register to attend any ETC course. In addition, the Centre will rent facilities and provide assistance to individuals and organizations wishing to conduct their own training programs. The second-year of the Forest Technology program of the Northern Alberta Institute of Technology is presently taught at the Centre. For further information contact Director, Environmental Training Centre, 1176 Switzer Drive, Hinton, Alberta T7V 1V3 or phone 403-865-8200.
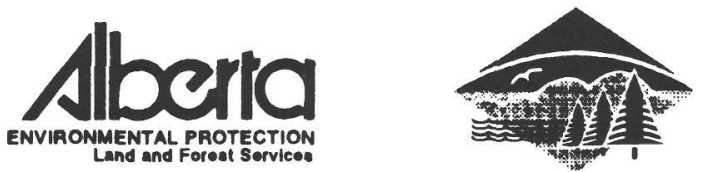

ONTARIO ADVANCED FORESTRY PROGRAM, School of Forestry, Lakehead University, Thunder Bay, Ontario P7B 5E1. The Ontario Advanced Forestry Program is designed to develop resource manager's skills through a comprehensive study of the biology, ecology, economics and silviculture of contemporary forest management. Prominent educators and managers will re-examine scientific principles, present current research and lead discussions on problem solving, operational applications and their implications. The program consists of six two-week modules that are offered annually. Entrance Requirements: The normal requirement is a Bachelor's degree in forestry or a related discipline and extensive experience in resource management. Resource technicians will also be considered. For further information, contact Director of O.A.F.P., Laird Van Damme at the above address or call (807) 343-8330.

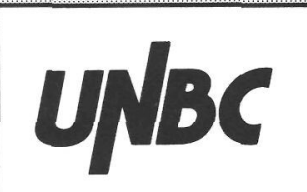

THE UNIVERSITY OF NORTHERN BRITISH COLUMBIA, Prince George, British Columbia.

The Faculty of Natural Resources and Environmental Studies offers BSC and MSc programs in Natural Resources Management with a major in Forestry. Other majors in Fisheries, Recreation and Wildlife are available. A PhD degree program in Natural Resources and Environmental Studies has been approved by Senate and may be available in 1996. The undergraduate Forestry major is designed to meet national accreditation standards as well as certification requirements for the Association of $\mathrm{BC}$ Professional Foresters. The 4year program of study includes two years in common with the other majors plus a number of shared courses in areas like natural resource economics, resource planning, issues and ethics and a field camp during the junior or senior year. The intent is to provide a broad interdisciplinary renewable natural resource base with specialization in the final two years. Cooperative education opportunities are available. UNBC's Prince George campus is strategically located in the center of the province, amidst the province's major forestry resource base, and thus the Faculty has access to a wide range of forest types. The university is involved in a number of model and research forests allowing the students extensive hands-on experience. The Faculty of Natural Resources and Environmental Studies helps to train the managers and scientists needed to effectively meet the demands for services and products from natural resources and still maintain a quality environment. The wise and sustainable use of our forest, fisheries, recreational and wildlife resources is a potent driver of our educational mission. Supported by programs in Resources Recreation/Tourism, Environmental Studies, Geography and Biology, the Forestry faculty will focus its research on issues that affect northem British Columbia and similar regions elsewhere in the world. Please direct enquiries to the Chair of the program, 3333 University Way, Prince George, BC, V2N 4Z9. Telephone: (604) 9606661. Fax: (604) 960-5538/5539.

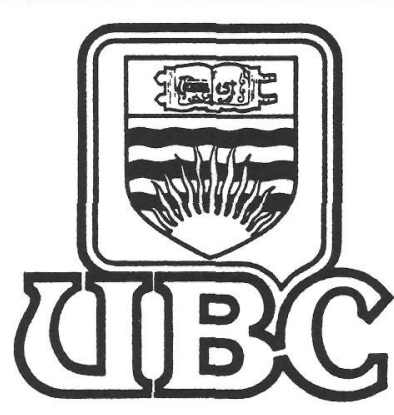

A CIF/IFC Corporate Sustaining Member 


\section{FORESTRY EDUCATION}

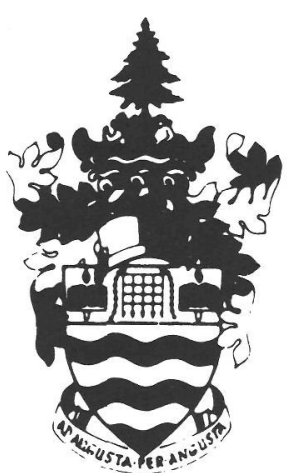

LAKEHEAD UNIVERSITY, Thunder Bay,

Ontario P7B 5E1. The school of Forestry

recently revised its Honours Bachelor of

Science in Forestry program to reflect substantive changes in the role of the forestry professional. Foresters will succeed to the extent that they are able to manage change and deal with people - technical knowledge must be combined with skills in problem solving, decision making, communications and group dynamics. The academically rigorous program consists of $\mathbf{4 8}$ single-term course equivalents - two of which are used for the final year thesis project while eight are dedicated to electives. The program is available in two formats - the traditional four-year and five-year Co-operative Education option. The HBScF program is nationally accredited by the Canadian Forestry Accreditation Board. This signifies that graduates of the program meet the academic requirements for membership in provincial professional foresters associations in British Columbia, Alberta, Ontario, Quebec and New Brunswick. The school's location on the boundary of the Boreal and Great Lakes-St. Lawrence forest regions allows immediate access to a wide variety of forest related activities. Close ties with local administrative, operational and research branches of large and small companies as well as provincial and federal government departments increase the opportunities for joint projects and professional exchanges. Class sizes encourage student/faculty interaction and allow access to specialized equipment such as the Geographic Information System operated through the LU-Centre for the Application of Resource Information Systems (LU-CARIS). Of particular interest to forestry diploma graduates is our streamlined transfer program. Forest Technician/ Technologists with a minimum $70 \%$ overall average can complete the regular H.B.Sc.F. in three years. Graduate programs leading to the M.Sc.F. and M.F. degrees are offered in a variety of disciplines. Please direct enquiries regarding any of our programs to the address given above or call (807) 343-8507.

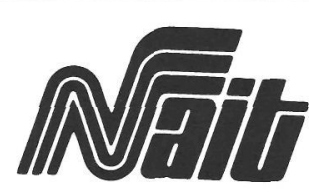

NORTHERN ALBERTA INSTITUTE OF TECHNOLOGY offers a two-year diploma in Forest Technology. The program emphasizes training in establishing, tending, protecting, and harvesting forest crops. The first year of the program begins with a five-week field camp, with the balance of the year taught at the main campus in Edmonton. The second year is delivered at the Forest Technology School at Hinton, Alberta. There is a balance between classroom/ laboratory and field work in both first and second year. Applicants require the equivalent of an Alberta General High School Diploma or equivalent including English 30 or 33, Mathematics 30 or 33 , Biology 20 and Chemistry 20, with preference given to applicants with 30 -level sciences, St. John Ambulance Standard First Aid Certificate and CPR heartsaver. For further information contact the Registrars office at 1-800-661-4077.

\section{AlGONGUIN}

ALGONQUIN COLLEGE OF APPLIED ARTS AND TECHNOLOGY, Pembroke, Ontario, K8A 3K2. The two-year Forestry Technician Diploma Program utilizes the nearby forests of Algonquin Park and the Ottawa Valley. This unique location offers students access to agencies such as the Petawawa National Forestry Institute, Algonquin Forestry Authority, the local Ministry of Natural Resources and a diverse group of forest companies. An emphasis on practical field experience brings theoretical principles into perspective for the students. Graduation can lead directly to a career in natural resources management or to further education including the multi-discipline, one-year, post-graduate Environmental Studies Program. Admission requirements for Algonquin's Forestry Program are Ontario Secondary School Diploma (or equivalent) with technical math and English, or mature standing. For further information, contact Admissions at (613) 735-4708 or the Co-ordinator, B. Middleton (613) 735-4741.

THE UNIVERSITY OF ALBERTA, EDMONTON, ALBER-
TA, T6G 2H1. The Faculty of Agriculture, Forestry and Home
Economics offers six undergraduate degree programs,
including a B.Sc. Degree in Forestry and a B.Sc. Degree
in Environmental and Conservation Sciences. Under
these two degree programs students may major in forest

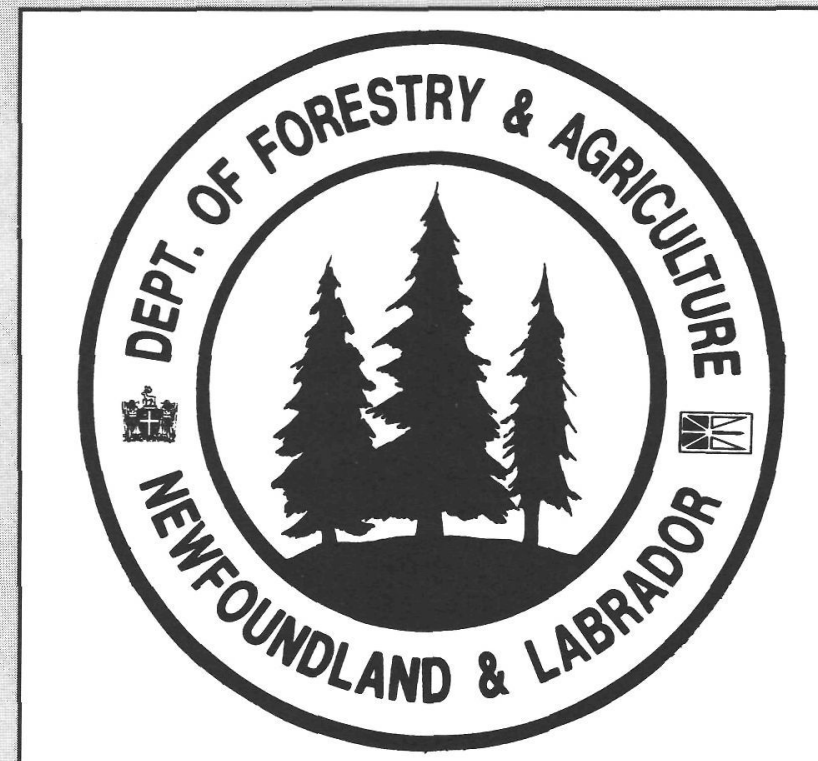

A CIF/IFC Corporate Sustaining Member

\section{(1) \\ Alberta Vocationa College} Lac La Biche
Alberta Vocational College Lac La Biche. The Forest Technician Program is a oneyear training program designed to prepare individuals in practical skills for the forest industry (private sector or government). The program consists of in-classroom lectures which provide the basis for field training exercises. Subject areas are: Forest Management, Forest Land Use, Communications, Equipment and Safety, Forest Measurement, Harvesting, Wood Utilization, Silviculture, Outdoor Skills, Forest Protection, Work Experience and Fitness. The training and practical field experience provide graduates with a sound background in forestry skills to obtain employment within the forest industry. The program also provides a significant base for advancement for more technical or professional training. For further information contact: Admissions Department, Alberta Vocational College, Box 417, Lac La Biche, AB TOA 2C0, Phone: (403) 623-5580 or toll free (Alberta only) 310-0000 (and ask for AVC LLB). 